\title{
RELACIJE MORFOLOŠKIH VARIJABLI I NORMALNIH I PATOLOŠKIH KONATIVNIH KARAKTERISTIKA RUKOMETAŠA
}

\author{
Veroljub Stanković ${ }^{1}$, Julijan Malacko², Ivana Bojić ${ }^{3}$ i Jelena Ilić ${ }^{4}$ \\ ${ }^{1}$ Fakultet za sport i fizičko vaspitanje, Univerzitet u Prištini, Srbija \\ ${ }^{2}$ Fakultet sporta i fizičkog vaspitanja, Univerzitet u Novom Sadu, Srbija \\ ${ }^{3}$ Fakultet sporta i fizičkog vaspitanja, Univerzitet u Nišu, Srbija \\ ${ }^{4}$ Zavod za sport i medicinu sporta Republike Srbije, Beograd, Srbija
}

\section{SAŽETAK}

Cilj istraživanja je ispitivanje relacija morfoloških, normalnih i patoloških konativnih karakteristika rukometaša Prve rukometne lige Srbije. U istraživanju je primijenjen sistem od 51 varijable (23 antropometrijske, 16 normalnih konativnih i 12 patoloških konativnih varijabli). Podaci su prikupljeni na prigodnom uzorku ( $N=71)$ i obrađeni pomoću kanoničke korelacione analize. Rezultati pokazuju da između sistema antropometrijskih varijabli i sistema normalnih konativnih karakteristika postoji kanonička korelacija $(R=0,80 ; p<0,00)$, a između sistema normalnih i patoloških konativnih karakteristika dobijene su dvije statistički značajne korelacije $\left(R_{c}=0,69 ; \mathrm{p}<0,00\right.$ i $\left.\mathrm{R}_{c}=0,62 ; p<0,02\right)$. Rukometaši ektomezomorfnog tipa se karakterišu na jednom polu longitudinalnim mjerama a na drugom transverzalnom dimenzionalnošću obimom femoralne regije ako imaju povećane vrijednosti u konativnim varijablama, ekstraverti su i neanksiozni. Kod rukometaša koji su ljubazni i pažljivi prema drugima postoji porast skorova na depresivnosti kao i kod onih koji pokazuju izraženiju živahnost i impulsivnost i ekspresivnost. Rukometaši koji češće manifestuju dominantno, takmičarsko, asertivno ili čak agresivno ponašanje su anksiozniji, dok su oni koji su moralniji i više poštuju pravila su skloniji hipersenzitivnosti. Oni koji su neustrašiviji i avanturističkog duha imaju više skorove na opsesivnosti. Napeti, energični i nestrpljivi rukometaši češće razvijaju gastrointestinalnu konverziju, hipohondriju i fobičnost.

Ključne riječi: konativne relacije, morfologija, rukomet, Srbija.

\section{UVOD}

Rukomet je zahtijevan kontaktni, ekipni sport koji u svojoj strukturi sadrži elementarne pokrete kao što su trčanje, skakanje, sprint, zamahivanje, udaranje, blokiranje i guranje uz interaktivni kontakt sa protivnikom tokom igre (Vrbik, Čizmek i Grujić, 2011). Uspjeh u rukometu zavisi od velikog broja spoljašnjih i unutrašnjih faktora. Prema nekim autorima (Gabrijelić, 1977; Ilić, 1993; Pokrajac, 1983), u jednačini specifikacije sportskog rezultata učestvuje čak 13 faktora (morfološki, motorički, funkcionalni, konativni, kognitivni, motivacioni, sociološki, zdravstveni i dr.).

Iako se pod morfološkim karakteristikama antropološkog statusa čovjeka najčešće podrazumi- jevaju procesi rasta i ontogenetskog razvoja on za svoju osnovu ima interakciju svih antropoloških morfoloških karakteristika i u znatnoj mjeri je određen endogeno i egzogeno uslovljenim činiocima. Postoji veliki broj istraživanja koja su se bavila morfološkim karakteristikama rukometaša (Popović-Ilić, Stanković, Vitošević i Ilić, 2010; Srhoj, Marinović i Roguli, 2002; Šentija, Matković, Vuleta, Tomljanović i Džaj, 1997; Šibila i Pori, 2009; Vrbik i saradnici, 2011), kao i relacijama njihovih antropometrijskih i psiholoških karakteristika. U njima je identifikacija latentnih varijabli u morfološkom prostoru vršena najčešće pomoću faktorske analize, a sve su više bile prisutne i metode taksonomskih (cluster) algoritama, sa ciljem da se najprije utvrdi morfološka struktura ljudskog 
organizma, a zatim i relacije ovih karakteristika sa drugim antropološkim osobinama, sposobnostima i karakteristikama, kao i koliko one doprinose uspjehu u sportskom stvaralaštvu (Malacko i Popović, 2001; Popović i Simonović, 2008; Stanković, 2000; Stanković i Malacko, 2008; Stanković, Malacko i Doder, 2011; Stanković i Popović, 2011; Szirovicza, Momirović, Hošek i Gredelj, 1980).

Neke morfološke karakteristike sportista imaju visok stepen povezanosti s uspjehom u sportu (Stanković, 2001). Utvrđeno je da u sportskim igrama, visoki sportisti, dužih ruku i nogu imaju određenu prednost pred nižim sportistima, odnosno onima s kratkim ekstremitetima. Zatim, da su sportisti s velikom količinom masnog tkiva inferiorni u odnosu na one $\mathrm{s}$ istom težinom, ali bez ovog nepotrebnog balasta. Veliki broj istraživanja koje se bave transformacijama morfoloških karakteristika (Popović-Ilić i saradnici, 2010; Srhoj i saradnici, 2002; Šentija i saradnici, 1997; Šibila i sarardnici, 2009; Vrbik i saradnici, 2011), ukazuje na njihovu veliku složenost s obzirom da su one pod uticajem kako genetskih faktora tako i faktora okoline, pri čemu treba istaći da uticaj genetskih faktora nije isti za sve latentne morfološke dimenzije. Analizom latentnih dimenzija morfoloških varijabli dobijena su riješenja koja su se mogla taksonomski interpretirati i to ona odgovorna za rast kostiju u dužinu, odnosno longitudinalnu dimenzionalnost skeleta, odgovorna za masu tijela i cirkularnu dimenzionalnost, potkožno masno tkivo i transverzalnu dimenzionalnost skeleta. Utvrđeno je da je kod rukometaša moguće govoriti o ektomezomorfiji. Bikristalni raspon ili druga horizontalna osovina tijela odgovornija je za harmoničan i biomehanički funkcionalniji morfološki razvoj od prve horizontalne osovine tijela.

U istraživanju koje su sproveli Stanković i saradnici (2009), utvrđeno je da za razliku od košarkaša i fudbalera, rukometaši imaju povećane vrijednosti u mekim tkivima, definisanim količinom mišićne mase i potkožnog masnog tkiva. U vezi s tim, u stručnoj i naučnoj literaturi je poznato da volumen mišića ima direktnog uticaja na sposobnost razvijanja snage $u$ mišićima, te samim tim definiše i mogućnost većeg ili manje efikasnog kretanja, savladavanja otpora ili prepreka. Iako potkožno masno tkivo u motoričkim manifestacijama sportista predstavlja balastnu masu, veoma je važno ne zanemariti potrebu za optimalnom količinom masnog tkiva, s obzirom da ono sadrži masne kiseline koje su nužne u ljudskom organizmu za odvijanje najrazličitijih hemijskih procesa, ali i za izgradnju pojedinih tkiva i proizvodnju energije.

Konativne karakteristike su odgovorne za modalitete ljudskog ponašanja i određuju se kao latentne strukture od kojih zavise modaliteti reagovanja $\mathrm{u}$ odnosu na sebe, druge ljude i društvo u cjelini, kao i karakteristični modaliteti emocionalnog reagovanja i određuju način, oblik i stabilnost, ali ne i intenzitet reagovanja (Pajević, 2003). Kako postoje normalni i patološki modaliteti ponašanja, tako se i konativne karakteristike mogu podijeliti na normalne i patološke. Normalne konativne karakteristike, odnosno faktori, su najčešće međusobno nezavisne i normalno distribuirane u populaciji. One integrišu ego i omogućavaju dinamičku i efikasnu komunikaciju sa sredinom. Različiti autori dobijali su često veoma različite rezultate u pogledu strukture normalnih konativnih karakteristika pa su se shodno tome, formirale i različite teorije ličnosti. Kao teorijski okvir u ovom radu je korišćena Katelova teorija ličnosti koja podrazumeva da postoji 16 faktora. Naime, Katel (1978) smatra da je ličnost ono što nam pokazuje šta će osoba učiniti kada se nađe u određenoj situaciji. Ponašanje čovjeka je proizvod situacije u kojoj se nalazi i karakteristika njegove ličnosti. On vidi ličnost kao složen i diferenciran sklop crta sa motivacijom koja uveliko zavisi od podskupa dinamičkih crta, koje se odnose na stupanje pojedinca u akciju usmjerenu ka ostvarenju nekog cilja.

Za konativne karakteristike je poznato da su one povezane sa smanjenjem ili povećanjem adaptivne moći, a one patološke izazivaju poremećaje u integraciji ličnosti, čime se vrši narušavanje ravnoteže između procesa razdraženja i kočenja, kao i da postoji relativan uticaj dispozicije na većinu pojedinačnih karakteristika ili grupa tih karakteristika ličnosti kao i da su one pretežno genetski uslovljene (Popović i Simonović, 2008; Powell i Royce, 1981). One umanjuju adaptacione sposobnosti pojedinca i njihova distribucija u populaciji nije normalna budući da većina ljudi na ovim faktorima ima niske vrijednosti (Pajević, 2003).

Ali, treba dodati i to da konativni regulatorni mehanizmi koji imaju zadatak da neutrališu posledice različitih smetnji (odnosno, da proizvedu adaptibilno ponašanje ili emocionalnu stabilnost), mogu i sami postati smetnja onoga trenutka kada pređu određeni prag regulacije. Zajednička karakteristika obe vrste konativnih dimenzija (normalnih i patoloških) je da određuju oblike ponašanja i reagovanja, čime djeluju na adaptacionu i akcionu efikasnost.

Još početkom XX vijeka, Šeldon i Krečmer su pokušali da uspostave tipologiju ličnosti na osnovu tjelesne konstitucije. Krečmer (1925/1970) je tvrdio da su osobe sa pikničkom građom sklone manično - depresivnoj psihozi dok astenični tip odlikuje šizoidna ličnost sa tendencijom ka razvijanju šizofrenije. Šeldon 
(Sheldon \& Stevens, 1942) tvrdi da se pomoću niza mjernih podataka o tjelesnoj građi može dobiti izvjesna slika i o ispoljavanju tih činilaca. Morfogenotip, kao hipotetički biološki sklop, koji leži u osnovi spoljne, opažljive telesne građe (fenotipa) ima i važnu ulogu ne samo u određivanju fizičkog razvoja nego i u obličavanju ponašanja. Somatotip predstavlja kompromis između morfogenotipa i fenotipa. Ispitivanjem povezanosti somatotipa i tipova temperamenta, ustanovio je da su kod endomorfa prisutne osobine koje odlikuju viscerotoni tip temperamenta a to su sklonost ka udobnosti, druželjubivost, pohlepnost za hranom te potreba za ljubavlju i nježnošću. Opušteni su, sporo reaguju, uravnotežene su naravi, tolerantni i saradljivi. Mezomorfe odlikuju osobine poput ljubavi ka bavljenju fizičkim aktivnostima i sklonost riziku koje su karakteristične za somatotoni tip. Ovaj tip temperamenta odlikuju još i agresivnost, neosjetljivost za osjećanja drugih, zreo izgled, bučno ponašanje, hrabrost $\mathrm{i}$ klaustrofobičnost a osnovne vrijednosti su mu akcija, moć i nametanje. Ektomorfe odlikuje hipersenztivnost u odnosu na stimuluse koji potiču iz spoljašnje sredine, okrenuti su sebi i nalaze zadovoljstvo u razmišljanju, težnja ka povlačenju u sebe i samoći, što su karakteristike cerebrotonog tipa temperamenta kao i uzdržanost, ukočenost, tajnovitost, stidljivost, mladolikost, strah od ljudi a najsretniji su u malim i izolovanim prostorima. Osoba reaguje brzo, ima loš san i pokušava da izbegne privlačenje pažnje na sebe (Hol i Lindzi, 1983).

Herdis, Deabler, Hartl i Willis (1973) su u istraživanju sprovedenom na 300 ratnih veterana pokušali da ustanove da li postoji povezanost između Šeldonovih somatotipova i Katelovih faktora ličnosti. Dobili su da endomorfni i ektomorfni somatotipovi nisu značajno korelirali sa Katelovim faktorima ličnosti. Osim faktora L, koji je pozitivno korelirao sa mezomorfnim tipom, ovaj tip je zabilježio i negativne, statistički značajne korelacije (iako veoma niskog intenziteta) i sa faktorima visoke/niske ergičke tenzije Q4 (smirenost - razdražljivost), kristalizovane inteligencije B i faktorom snage ega $\mathrm{C}$ koji predstavlja emocionalnu (ne)stabilnost. Mezomorfni ("sportski") tip veterana je odlikovala veća sumnjičavost, ljubomora i smirenost, niži nivo kristalizovane inteligcije i manja emocionalna stabilnost.

Cilj ovog istraživanja je bio ispitati da li postoje statistički značajne relacije između sistema morfoloških karakteristika, normalnih konativnih karakteristika i patoloških konativnih karakteristika, kako bi se preciznije utvrdilo koje sve antropološke karakteristike odlikuju uspješne rukometaše, koji su izborili svoje mjesto u Prvoj ligi.

\section{METODE}

\section{Uzorak ispitanika}

Uzorak je bio prigodan i činio ga je 71 rukometaš Prve savezne rukometne lige.

\section{Instrumenti}

Za procjenu morfoloških karakteristika korištene su slijedeće varijable:

Longitudinalna dimenzionalnost skeleta

- Visina tijela (VIS),

- Dužina noge (DNO),

- Dužina šake (DSA),

- Dužina stopala (DST),

- Dužina ruke (DRU),

- Biakromialni raspon (BIA).

Transverzalna dimenzionalnost skeleta

- Bikristalni raspon (BIK),

- Širina šake (SSA),

- Dijametar ručnog zgloba (DIR),

- Dijametar lakta (DIL),

- Dijametar koljena (DIK),

- Širina stopala (SST).

Cirkularna dimenzionalnost i masa tijela

- Masa tijela (MAS),

- Obim nadlaktice (ONA),

- Obim podlaktice (OPO),

- Obim natkoljenice (ONT),

- Obim potkoljenice (OPT),

- Srednji obim grudnog koša (OGK).

Potkožno masno tkivo

- Kožni nabor nadlaktice (KNA),

- Kožni nabor leđa (KLE),

- Kožni nabor pazuha (KPA),

- Kožni nabor trbuha (KTR),

- Kožni nabor potkoljenice (KPT).

Za procjenu normalnih konativnih karakteristika korišćena je baterija 16PF (Cattell, Eber i Tatsuoka, 1970) sa faktorima prvog reda:

- Afektotimija - sajzotimija (A),

- Viša inteligencija - niža inteligencija (B),

- Snažan ego -slab ego (C),

- Dominacija - samopotčinjavanje (E),

- Surgencija - desurgencija (F),

- Snažan super ego - slab super ego (G),

- Neustrašivost (parmija) -strašljivost (H),

- Meka narav (premsija) -oštra narav (I),

- Protensija (L),

- Autija (uobrazilja) - praktičnost $(\mathrm{M})$, 
- Oštroumnost (fitmija) - prostodušnost $(\mathrm{N})$,

- Psihostenija (O),

- Tradicionalizam -liberalizam (Q1),

- Individualizam - grupna zavisnost (Q2),

- Dobra samokontrola- self konflikt (Q3),

- Visoka ergička tenzija - niska ergička tenzija (Q4).

Patološke konativne karakteristike su operacionalizovane preko skora na odabranim skalama na testu patoloških konativnih karakteristika (Momirović, 1971), C.I.-N4 - efikasnost sistema za regulaciju i kontrolu organskih funkcija (HI):

- Kardiovaskularna konverzija (K10),

- Gastrointestinalna konverzija (G11),

- Inhibitorna konverzija (I7),

- Hipohondrija (H13), efikasnost sistema za regulaciju i kontrolu reakcija odbrane (ALPHA),

- Anksioznost (A1),

- Opsesivnost (O3),

- Hipersenzitivnost (S5),

- Fobičnost (F2), efikasnost sistema za regulaciju i kontrolu reakcije napada (SIGMA),

- Impulsivnost (N14),

- Agresivnost (T15) i efikasnost sistema za koordinaciju regulativnih funkcija (DELTA),

- Paranoidnost (P18),

- Depresivnost (D6).

\section{Metode obrade podataka}

Prilikom izračunavanja relacija između sistema varijabli morfoloških karakteristika, normalnih i patoloških konativnih karakteristika bila je korišćena kanonička korelaciona analiza.

\section{REZULTATI}

Rezultati deskriptivne statistike za sve varijable su date u Tabeli 1.

Analizom matrice kroskorelacija između sistema antropometrijskih varijabli i sistema normalnih konativnih varijabli (Tabela 2) uočavaju se statistički značajne korelacije parova varijabli između umjerenog broja analiziranih varijabli lijevog i desnog seta. Faktori ličnosti koji nisu zabilježili nijednu statistički značajnu korelaciju sa setom antropometrijskih varijabli su: snažan ego -slab ego (C), snažan super ego - slab super ego (G) i meka narav (premsija) -oštra narav (I), dok su varijable iz seta antropometrijskih varijabli, koje nisu zabilježile nijednu statistički značajnu korelaciju sa faktorima ličnosti prvog reda bile dužina noge (DNO), bikristalni raspon (BIK), širina stopala (SST), obim nadlaktice (ONA), srednji obim grudnog koša (OGK), kožni nabor leđa (KNL), kožni nabor potkolenice (KP'T).
Dalje je kanoničkom korelacionom analizom ispitivana povezanost između multivarijantnog sistema antropometrijskih varijabli i sistema normalnih konativnih varijabli i dobijeno je da postoji statistički značajna povezanost između ovih faktora $\left(R_{c}=0,89\right.$, $p<0,00)$.

Iz rezultata sadržanih u matrici kanoničke strukture antropometrijskih i normalnih konativnih varijabli (Tabela 3) uočava se statistički značajna korelacija između antropometrijskih varijabli i prvog kanoničkog faktora. Izolovani prvi kanonički faktor je definisan relativno visokim vrijednostima statistički značajnih kanoničkih koeficijenata korelacije. S obzirom da strukturu prvog izolovanog kanoničkog faktora sačinjavaju varijable dužina stopala (DST), dužina ruke (DRU), širina šake (SSA), dijametar ručnog zgloba (DIR), dijametar koljena (DIK) i obim potkoljenice (OPT) on predstavlja kombinaciju ektomezomorfnog sportskog tipa. U istoj tabeli prikazana je i matrica strukture kanoničkih faktora normalnih konativnih varijabli koja pokazuje da postoje veoma visoke korelacije između primijenjenih varijabli i kanoničkog faktora. S obzirom da izolovani kanonički faktor prezentuje sedam konativnih varijabli: afektotimija - sajzotimija (A), viša inteligencija - niža inteligencija (B), neustrašivost (parmija) - strašljivost $(\mathrm{H})$, meka narav (premsija) - oštra narav (I), protensija (L), individualizam - grupna zavisnost (Q2), visoka ergička tenzija - niska ergička tenzija (Q4) očigledno se radi o jednom složenom faktoru.

Iz analize matrice kroskorelacija između sistema normalnih i sistema patoloških konativnih karakteristika (Tabela 4) uočavaju se takođe statistički značajne korelacije parova varijabli jednog i drugog antropološkog prostora. Statistički značajne korelacije normalnih i patoloških konativnih karakteristika imaju slijedeće varijable: afektotimija - sajzotimija (A) i depresivnost (D6); dominacija -samopotčinjavanje (E) sa kardiovaskularna konverzija (K10), gastrointestinalna konverzija (G11), inhibitorna konverzija (I7), anksioznost (A1); surgencija -desurgencija (F) i depresivnost (D6); snažan superego-slab superego $(G)$ sa hipersenzitivnost (S5); neustrašivost-strašivost (H) sa opsesivnost (O3); protensia (L) sa kardiovaskularna konverzija (K10); oštroumnost - prostodušnost $(\mathrm{N})$ sa inhibitorna konverzija (I7), anksioznost (A1), fobičnost (F2) i impulsivnost (N14); psihostenija (O) sa agresivnost (T15); tradicionalizam - liberalizam (Q1) sa hipohondrija (H13), opsesivnost (O3), paranoidnost (P18); individualizam - grupna zavisnost (Q2) sa opsesivnost (O3); dobra samokontrola - self konflikt (Q3) sa gastrointestinalna konverzija (G11), inhibitorna konverzija (I7), impulsivnost (N14); visoka ergička ten- 


\section{TABELA 1}

Bazicni statistički parametri.

\begin{tabular}{|c|c|c|c|c|c|c|c|c|c|c|c|c|}
\hline \multicolumn{7}{|c|}{ Antropometrijske varijable } & \multicolumn{3}{|c|}{$\begin{array}{c}\text { Patološke } \\
\text { konativne varijable }\end{array}$} & \multicolumn{3}{|c|}{$\begin{array}{l}\text { Faktori ličnost } \\
\text { (sirovi skorovi) }\end{array}$} \\
\hline Var. & $\mathrm{M}$ & Min & Max & $\mathrm{SD}$ & Skew. & Kurt & Var. & $\mathrm{M}$ & $\mathrm{SD}$ & Var. & $\mathrm{M}$ & $\mathrm{SD}$ \\
\hline VIS & 1815,18 & 1626 & 1960 & 62,632 & $-0,269$ & 0,321 & K10 & 2,60 & 1,625 & A & 12,67 & 8,724 \\
\hline $\mathrm{DNO}$ & 1032,00 & 940 & 1180 & 47,547 & 0,250 & 0,295 & G11 & 0,84 & 1,327 & $\mathrm{~B}$ & 7,15 & 2,162 \\
\hline DSA & 196,09 & 170 & 235 & 11,015 & 0,564 & 1,323 & I7 & 1,31 & 1,293 & $\mathrm{C}$ & 16,16 & 3,492 \\
\hline DST & 279,67 & 260 & 310 & 12,664 & 0,817 & 0,560 & $\mathrm{H} 13$ & 0,23 & 0,818 & $\mathrm{E}$ & 15,43 & 4,298 \\
\hline DRU & 782,47 & 690 & 880 & 49,924 & $-0,211$ & $-0,220$ & A1 & 0,21 & 0,674 & $\mathrm{~F}$ & 15,33 & 3,422 \\
\hline BIA & 414,31 & 312 & 540 & 30,129 & 0,385 & 4,664 & $\mathrm{O} 3$ & 0,29 & 0,900 & $G$ & 9,77 & 1,987 \\
\hline BIK & 299,16 & 245 & 390 & 25,861 & 0,731 & 2,183 & S5 & 0,40 & 0,903 & $\mathrm{H}$ & 15,62 & 3,969 \\
\hline SSA & 85,67 & 75 & 100 & 5,442 & 0,092 & $-0,362$ & $\mathrm{~F} 2$ & 1,19 & 1,489 & $\mathrm{I}$ & 6,57 & 3,059 \\
\hline DIR & 58,54 & 53 & 68 & 3,022 & 0,219 & 0,152 & N14 & 0,59 & 0,887 & $\mathrm{~L}$ & 10,38 & 2,963 \\
\hline DIL & 74,78 & 62 & 88 & 6,581 & 0,225 & $-0,500$ & T15 & 0,54 & 0,841 & $\mathrm{M}$ & 10,26 & 2,699 \\
\hline DIK & 92,38 & 76 & 105 & 5,909 & 0,177 & $-0,399$ & P18 & 1,45 & 1,528 & $\mathrm{~N}$ & 10,70 & 2,647 \\
\hline SST & 92,22 & 69 & 110 & 7,878 & $-0,407$ & 0,608 & D6 & 1,14 & 0,682 & $\mathrm{O}$ & 10,21 & 3,193 \\
\hline MAS & 788,52 & 550 & 1080 & 110,893 & 0,426 & $-0,286$ & & & & Q1 & 9,19 & 2,974 \\
\hline ONA & 283,38 & 230 & 370 & 25,285 & 0,745 & 0,940 & & & & Q2 & 10,11 & 2,733 \\
\hline OPO & 269,15 & 220 & 320 & 21,027 & 0,275 & $-0,050$ & & & & Q3 & 12,64 & 2,844 \\
\hline ONT & 561,83 & 480 & 680 & 45,428 & 0,653 & $-0,066$ & & & & Q4 & 9,95 & 3,852 \\
\hline OPT & 392,25 & 320 & 600 & 48,820 & 2,097 & 6,215 & & & & & & \\
\hline OGK & 956,62 & 840 & 1110 & 69,548 & 0,249 & $-0,717$ & & & & & & \\
\hline KNN & 94,01 & 36 & 198 & 36,395 & 0,940 & 0,687 & & & & & & \\
\hline KNL & 104,93 & 66 & 214 & 33,835 & 1,695 & 2,805 & & & & & & \\
\hline KNP & 75,46 & 46 & 162 & 23,521 & 1,474 & 2,679 & & & & & & \\
\hline KNT & 116,57 & 50 & 432 & 62,879 & 2,547 & 9,261 & & & & & & \\
\hline KPT & 102,88 & 35 & 256 & 48,759 & 0,821 & 0,517 & & & & & & \\
\hline
\end{tabular}

Legenda: Var. - Varijable; Min - Minimum; Max - Makimium; $M$ - Aritmetička sredina; $S D$ - Standardna devijacija; Skew. - Skewnis; Kurt. - Kurtosis.

zija - niska ergička tenzija (Q4) sa gastrointestinalna konverzija (G11), hipohondrija (H13) i fobičnost (F2).

Rješavanjem karakterističnih jednačina kroskorelacione matrice izolovani su, kao korijeni tih jednačina, dva kanonička faktora. Prilikom ispitivanja relacija između sistema normalnih konativnih varijabli i sistema patoloških konativnih varijabli dobijene su relativno visoke kanoničke korelacije za oba izolovana kanonička faktora $(R=0,83$ i $R=0,79)$, i statistički su značajne na nivou $p<0,00$. Kvadrati kanoničke korelacije (Rc2), koji objašnjavaju zajedničku varijansu varijabli iz dva skupa od ukupnog varijabiliteta analiziranih sistema varijabli iznose $\mathrm{R}_{\mathrm{c}}^{2}=0,69, \mathrm{i}_{\mathrm{c}}{ }^{2}$ $=0,62$

$\mathrm{Na}$ osnovu dobijenih rezultata sadržanih u matrici kanoničke strukture normalnih i patoloških konativnih varijabli uočavaju se statistički značajne korelacije između primijenjenih varijabli kod prvog $\mathrm{i}$ drugog kanoničkog faktora. Prvi kanonički faktor u prostoru normalnih konativnih varijabli definisan je varijablama viša inteligencija - niža inteligencija (B), snažan ego - slab ego (C), neustrašivost (parmija) strašljivost $(\mathrm{H})$, meka narav (premsija) - oštra narav (I), protensija (L) tako da se on može definisati kao kanonički faktor koji karakteriše rukometaše u odnosu na inteligenciju, ego, neustrašivost, oštru narav i protensiu. Pošto drugi kanonički faktor definišu varijable individualizam -grupna zavisnost (Q2), dobra samokontrola - self konflikt (Q3), visoka ergička tenzija -niska ergička tenzija (Q4) i oštroumnost prostodušnost $(\mathrm{N})$ on se može interpretirati kao faktor introspekcije i oštroumnosti - prostodušnosti. Prvi kanonički faktor u prostoru patoloških konativnih varijabli definisan je varijablama kardiovaskularna konverzija (K10), gastrointestinalna konverzija (G11), 


\section{TABELA 2}

Kroskorelacije antropometrijskih i normalnih konativnih varijabli.

\begin{tabular}{|c|c|c|c|c|c|c|c|c|c|c|c|c|c|c|c|c|}
\hline & A & B & C & $\mathrm{E}$ & $\mathrm{F}$ & G & $\mathrm{H}$ & I & L & M & $\mathrm{N}$ & $\mathrm{O}$ & Q1 & Q2 & Q3 & Q4 \\
\hline VIS & 0,05 & $-0,12$ & $-0,09$ & $-0,04$ & $-0,31$ & $-0,12$ & 0,05 & 0,04 & 0,03 & 0,10 & $-0,08$ & 0,02 & $-0,08$ & $-0,19$ & $-0,10$ & $-0,02$ \\
\hline DNO & 0,17 & $-0,08$ & $-0,18$ & $-0,05$ & 0,23 & $-0,03$ & 0,09 & 0,12 & 0,11 & 0,02 & $-0,08$ & 0,06 & $-0,03$ & $-0,21$ & $-0,22$ & 0,00 \\
\hline DSA & 0,09 & $-0,02$ & $-0,11$ & $-0,09$ & $-0,10$ & $-0,13$ & $-0,01$ & 0,07 & 0,02 & 0,24 & $-0,31$ & $-0,02$ & $-0,10$ & $-0,22$ & $-0,23$ & $-0,02$ \\
\hline DST & 0,20 & 0,13 & 0,05 & $-0,01$ & $-0,07$ & $-0,08$ & 0,28 & 0,22 & 0,28 & 0,09 & $-0,07$ & 0,12 & $-0,06$ & $-0,00$ & $-0,11$ & 0,16 \\
\hline DRU & 0,26 & 0,04 & $-0,02$ & $-0,14$ & $-0,01$ & 0,00 & 0,23 & 0,21 & 0,14 & 0,05 & $-0,18$ & 0,02 & $-0,12$ & 0,06 & $-0,01$ & $-0,06$ \\
\hline BIA & 0,18 & 0,01 & $-0,10$ & $-0,30$ & $-0,16$ & 0,07 & $-0,15$ & $-0,04$ & $-0,08$ & 0,05 & $-0,12$ & 0,06 & $-0,07$ & $-0,23$ & $-0,07$ & $-0,10$ \\
\hline BIK & 0,04 & 0,00 & $-0,00$ & $-0,05$ & $-0,02$ & $-0,05$ & 0,12 & $-0,05$ & $-0,02$ & $-0,03$ & $-0,03$ & $-0,05$ & $-0,05$ & $-0,00$ & 0,03 & $-0,00$ \\
\hline SSA & $-0,23$ & $-0,19$ & 0,17 & $-0,09$ & $-0,05$ & $-0,14$ & 0,10 & 0,06 & $-0,02$ & 0,12 & $-0,32$ & 0,04 & 0,11 & $-0,24$ & $-0,27$ & $-0,15$ \\
\hline DIR & $-0,06$ & $-0,27$ & 0,09 & $-0,11$ & 0,00 & $-0,05$ & $-0,04$ & 0,02 & $-0,02$ & 0,30 & $-0,08$ & $-0,03$ & 0,01 & $-0,14$ & 0,22 & $-0,37$ \\
\hline DIL & $-0,02$ & $-0,08$ & 0,02 & $-0,23$ & $-0,16$ & 0,00 & $-0,11$ & 0,05 & $-0,15$ & 0,06 & $-0,32$ & 0,07 & 0,09 & $-0,01$ & $-0,08$ & $-0,17$ \\
\hline DIK & $-0,36$ & $-0,41$ & $-0,09$ & 0,18 & $-0,00$ & 0,02 & $-0,09$ & 0,14 & 0,14 & 0,04 & 0,07 & 0,10 & 0,36 & 0,01 & $-0,01$ & 0,04 \\
\hline SST & 0,08 & $-0,04$ & 0,05 & 0,13 & 0,13 & $-0,06$ & 0,00 & $-0,12$ & 0,21 & 0,00 & 0,12 & $-0,08$ & $-0,03$ & $-0,00$ & 0,10 & 0,08 \\
\hline MAS & $-0,09$ & $-0,13$ & $-0,04$ & $-0,02$ & $-0,03$ & $-0,10$ & 0,15 & 0,13 & 0,10 & 0,25 & $-0,01$ & $-0,08$ & 0,04 & $-0,20$ & 0,00 & $-0,02$ \\
\hline ONA & $-0,10$ & $-0,08$ & $-0,05$ & $-0,04$ & 0,03 & $-0,00$ & 0,10 & $-0,04$ & 0,17 & 0,09 & $-0,01$ & $-0,09$ & 0,09 & $-0,14$ & $-0,09$ & 0,00 \\
\hline OPO & $-0,12$ & $-0,16$ & 0,00 & 0,02 & $-0,05$ & 0,04 & 0,07 & 0,09 & $-0,05$ & 0,25 & 0,04 & $-0,04$ & 0,09 & $-0,14$ & $-0,01$ & $-0,17$ \\
\hline ONT & $-0,09$ & $-0,14$ & 0,02 & 0,01 & 0,10 & $-0,10$ & 0,19 & $-0,02$ & 0,11 & 0,24 & $-0,00$ & $-0,13$ & 0,11 & $-0,16$ & $-0,03$ & $-0,02$ \\
\hline OPT & $-0,09$ & $-0,37$ & 0,01 & 0,09 & 0,21 & 0,05 & 0,15 & $-0,03$ & $-0,00$ & 0,02 & 0,37 & 0,11 & 0,06 & $-0,04$ & 0,00 & 0,00 \\
\hline OGK & $-0,08$ & $-0,19$ & $-0,07$ & $-0,11$ & $-0,04$ & $-0,12$ & 0,09 & 0,04 & 0,13 & 0,15 & 0,01 & $-0,01$ & 0,11 & $-0,17$ & 0,01 & $-0,07$ \\
\hline KNN & $-0,02$ & 0,00 & 0,00 & 0,16 & 0,24 & 0,07 & 0,18 & $-0,01$ & 0,19 & 0,11 & 0,09 & $-0,20$ & 0,35 & 0,02 & $-0,06$ & 0,10 \\
\hline KNL & $-0,06$ & 0,00 & $-0,05$ & 0,10 & 0,09 & $-0,00$ & 0,07 & 0,01 & 0,05 & 0,21 & 0,11 & $-0,19$ & 0,22 & 0,13 & $-0,08$ & 0,10 \\
\hline KNP & $-0,13$ & $-0,10$ & $-0,08$ & 0,13 & 0,29 & 0,04 & 0,12 & 0,08 & 0,01 & 0,07 & 0,22 & $-0,12$ & 0,37 & 0,07 & 0,01 & $-0,00$ \\
\hline KNT & $-0,01$ & 0,19 & 0,00 & $-0,09$ & 0,22 & $-0,02$ & 0,06 & $-0,06$ & 0,04 & 0,12 & 0,03 & $-0,28$ & 0,08 & $-0,01$ & 0,10 & 0,02 \\
\hline KPT & $-0,15$ & $-0,05$ & 0,03 & 0,04 & 0,15 & $-0,00$ & 0,20 & $-0,03$ & 0,10 & 0,05 & $-0,03$ & $-0,21$ & 0,12 & $-0,00$ & 0,01 & 0,10 \\
\hline & & $\mathrm{R}_{c}$ & $\mathrm{R}_{c}^{2}$ & \multicolumn{2}{|c|}{$\chi^{2}$} & $p$ & & & & & & & & & & \\
\hline & & 0,89 & 0,80 & \multicolumn{2}{|c|}{440,70} & 0,00 & & & & & & & & & & \\
\hline
\end{tabular}

inhibitorna konverzija (I7) i paranoidnost (P18) i on se može definisati kao kanonički faktor efikasnosti sistema za regulaciju i kontrolu organskih funkcija i regulativnih funkcija. Pošto drugi kanonički faktor definišu varijable opsesivnost (O3), fobičnost (F2), impulsivnost (N14) i depresivnost (D6) on se može interpretirati kao kanonički faktor regulatora reakcija odbrane i napada.

Izmedu sistema antropometrijskih varijabli i sistema patoloških konativnih karakteristika nisu dobijene značajne relacije.

\section{DISKUSIJA}

Iz rezultata sadržanih u matrici kanoničke strukture antropometrijskih i normalnih konativnih varijabli (Tabela 3) uočava se statistički značajna korelacija između antropometrijskih varijabli i prvog kanoničkog faktora. Relacije između prvog kanoničkog faktora iz sistema antropometrijskih varijabli, interpretiranog kao bipolarni kanonički faktor ektomezomorfnog morfološkog tipa i prvog kanoničkog faktora iz sistema normalnih konativnih faktora, interpretiranog kao kanonički faktor ekstravertnost - introvertnost $i$ anksioznost, pokazuje, da se rukometaši ektomezomorfnog tipa karakterišu na jednom polu longitudinalnim merama a na drugom transverzalnom dimenzionalnošću obimom femoralne regije uz povećanje vrednosti u konativnim varijablama ekstravertnost i sniženu anksioznost.

Faktori prvog reda, C - snaga ega, G - snaga super ega i I - blaga - oštra narav nisu bili značajno povezani ni sa jednom mjerenom morfološkom varijablom. To je nalaz koji nije sasvim u skladu sa rezultatima koje su u svom istraživanju koje se bavilo razlikama u pogledu crta ličnosti sportista i nesportista dobili Havelka i Lazarević (1981). Naime, oni su dobili da se sportisti i nesportisti značajno razlikuju u pogledu faktora kristalizovane inteligencije $B$, snage ega C, snage super ega G, emocionalne osjetljivosti I, imaginativnosti $\mathrm{M}$ i samodovoljnosti Q2. Dakle, sportisti su u odnosu na nesportiste imali veću kristalizovanu inteligenciju, bili emocionalno stabiliniji, 
snažnijeg super ega, oštrije naravi i manje emocionalno osjetljivi, praktičniji, nesamostalniji i saradljiviji. Čini se da su rukometaši, u odnosu na druge sporiste specifični po tome što su manje emocionalno stabilni, sa nižom tolerancijom na frustracije i daleko manjom samokontrolom (što potvrđuje i korelacija dobijena u ovom istraživanju na relaciji snažan superego-slab superego $(G)$ sa hipersenzitivnost (S5), te manje savesni, realistični u svojim procjenama i nesamostalniji u procesu riješavanja problema (posmatrano u terminima Sten skorova).

$\mathrm{Na}$ osnovu dobijenih rezultata sadržanih u matrici kanoničke strukture normalnih i patoloških konativnih varijabli uočavaju se statistički značajne korelacije između mjerenih varijabli kod prvog i drugog kanoničkog faktora. Prvi kanonički faktor u prostoru normalnih konativnih varijabli se može definisati kao kanonički faktor koji karakteriše rukometaše u odnosu na inteligenciju, ego, neustrašivost, oštru narav i protensiu. Dok se drugi može interpretirati kao faktor introspekcije i oštroumnosti - prostodušnosti.
Prvi kanonički faktor u prostoru patoloških konativnih varijabli se može definisati kao kanonički faktor efikasnosti sistema za regulaciju i kontrolu organskih funkcija i regulatornih funkcija, dok se drugi kanonički faktor može interpretirati kao kanonički faktor regulatora reakcija odbrane i napada.

Strukture korelacija pokazuju da kod rukometaša kod kojih je izraženije toplo ponašanje, koji su ljubazniji, pažljiviji prema drugima postoji porast skorova na depresivnosti kao i kod onih koji pokazuju izraženiju živahnost 1 impulsivnost i ekspresivnost. Rukometaši koji češće manifestuju dominantno, takmičarsko, asertivno ili čak agresivno ponašanje u većoj su opasnosti da razviju neku od konverzija (kardiovaskularnu, gastrointestinalnu ili inhibitornu) i skloniji su anksioznosti. Oni koji su moralističniji i više poštuju pravila su skloniji hipersenzitivnosti a oni koji su neustrašiviji i avanturustički nastrojeniji imaju više skorove na opsesivnosti. Oni koji su sumnjičavi i skeptičniji pokazuju veću sklonost ka kardiovaskularnim konver-

TABELA 3

Kanonicke struk.tura antropometrijskih i normalnih konativnih varijabli.

Fc-1

Fc-1

\begin{tabular}{cccr} 
Antropometrijske varijable & Normalni konativni faktori \\
\hline VIS & $-0,07$ & A & $\mathbf{- 0 , 3 4}$ \\
\hline DNO & $-0,16$ & B & $\mathbf{- 0 , 4 2}$ \\
\hline DSA & 0,05 & C & 0,11 \\
\hline DST & $\mathbf{- 0 , 5 7}$ & E & $-0,21$ \\
\hline DRU & $\mathbf{- 0 , 3 7}$ & F & 0,02 \\
\hline BIA & 0,01 & G & $-0,02$ \\
\hline BIK & $-0,08$ & H & $\mathbf{- 0 , 3 6}$ \\
\hline SSA & $\mathbf{0 , 3 4}$ & I & $\mathbf{- 0 , 3 2}$ \\
\hline DIR & $\mathbf{0 , 3 0}$ & L & $\mathbf{- 0 , 4 5}$ \\
\hline DIL & 0,14 & M & 0,00 \\
\hline DIK & $\mathbf{0 , 3 0}$ & N & $-0,18$ \\
\hline SST & 0,01 & O & $-0,05$ \\
\hline MAS & $-0,00$ & Q1 & 0,09 \\
\hline ONA & 0,03 & Q2 & $\mathbf{- 0 , 2 6}$ \\
\hline OPO & 0,14 & Q3 & $-0,00$ \\
\hline ONT & 0,08 & Q4 & $\mathbf{- 0 , 4 0}$ \\
\hline OPT & $\mathbf{0 , 2 8}$ & & \\
\hline OGK & 0,00 & & \\
\hline KNN & $-0,04$ & & \\
\hline KNL & $-0,05$ & & \\
\hline KNP & 0,11 & & \\
\hline KNT & $-0,11$ & & \\
\hline KPT & $-0,01$ & & \\
\hline & & & \\
\hline
\end{tabular}




\section{TABELA 4}

Kroskorelacije normalnih i patoloških konativnih varijabli.

\begin{tabular}{|c|c|c|c|c|c|c|c|c|c|c|c|c|}
\hline & K10 & G11 & I7 & H13 & A1 & $\mathrm{O} 3$ & S5 & F2 & N14 & T15 & P18 & D6 \\
\hline$A$ & 0,07 & $-0,08$ & $-0,18$ & 0,01 & $-0,03$ & $-0,05$ & $-0,12$ & $-0,09$ & 0,05 & $-0,12$ & $-0,06$ & $-0,23$ \\
\hline B & 0,06 & 0,04 & 0,12 & 0,07 & $-0,09$ & 0,14 & $-0,08$ & $-0,02$ & $-0,04$ & 0,12 & 0,19 & 0,03 \\
\hline C & 0,19 & 0,15 & 0,20 & 0,18 & 0,06 & 0,22 & $-0,06$ & 0,07 & 0,07 & 0,20 & 0,22 & 0,08 \\
\hline $\mathrm{E}$ & 0,23 & 0,26 & 0,27 & 0,12 & 0,35 & $-0,04$ & 0,14 & 0,16 & 0,03 & $-0,03$ & 0,03 & 0,30 \\
\hline$F$ & $-0,10$ & 0,09 & 0,19 & $-0,06$ & $-0,03$ & 0,22 & 0,05 & $-0,10$ & 0,10 & 0,17 & $-0,04$ & 0,23 \\
\hline$G$ & 0,02 & 0,10 & 0,10 & 0,01 & 0,10 & 0,03 & 0,23 & 0,01 & 0,04 & 0,12 & 0,04 & 0,07 \\
\hline $\mathrm{H}$ & 0,12 & 0,13 & 0,20 & 0,00 & 0,19 & 0,24 & $-0,06$ & $-0,01$ & $-0,00$ & 0,10 & 0,02 & 0,04 \\
\hline $\mathrm{I}$ & 0,13 & $-0,03$ & $-0,08$ & $-0,20$ & 0,18 & 0,00 & 0,01 & $-0,10$ & 0,14 & $-0,15$ & $-0,03$ & 0,11 \\
\hline $\mathrm{L}$ & 0,26 & 0,10 & 0,14 & 0,12 & 0,20 & $-0,16$ & 0,02 & 0,18 & $-0,08$ & $-0,03$ & $-0,10$ & $-0,04$ \\
\hline M & 0,08 & 0,05 & $-0,04$ & $-0,04$ & 0,05 & 0,20 & 0,02 & $-0,00$ & 0,07 & 0,02 & 04 & 0,08 \\
\hline $\mathrm{N}$ & 0,08 & 0,19 & 0,25 & 0,16 & 0,24 & 0,08 & 0,13 & 0,23 & 0,25 & $-0,03$ & 0,04 & 0,14 \\
\hline $\mathrm{O}$ & $-0,01$ & 0,09 & $-0,04$ & $-0,05$ & 0,01 & $-0,10$ & 0,07 & $-0,08$ & $-0,13$ & $-0,25$ & $-0,01$ & 0,02 \\
\hline Q1 & $-0,11$ & $-0,14$ & $-0,07$ & $-0,24$ & 0,13 & $-0,29$ & $-0,05$ & $-0,11$ & $-0,20$ & $-0,20$ & $-0,30$ & $-0,05$ \\
\hline Q2 & $-0,11$ & $-0,07$ & $-0,05$ & $-0,01$ & 0,14 & $-0,30$ & 0,05 & 0,07 & 0,14 & $-0,08$ & $-0,16$ & $-0,00$ \\
\hline Q3 & $-0,05$ & 0,28 & 0,24 & 0,19 & 0,16 & 0,06 & $-0,04$ & 0,18 & 0,23 & 0,15 & 0,08 & 0,07 \\
\hline $\mathrm{Q} 4$ & 0,06 & 0,31 & 0,14 & 0,39 & 0,10 & $-0,11$ & 0,17 & 0,29 & 0,15 & 0,01 & 0,03 & $-0,02$ \\
\hline & & $R_{c}$ & $\mathrm{R}_{c}^{2}$ & \multicolumn{2}{|c|}{$\chi^{2}$} & $p$ & & & & & & \\
\hline & & 0,83 & 0,69 & \multicolumn{2}{|c|}{262,94} & 0,00 & & & & & & \\
\hline & & 0,79 & 0,62 & \multicolumn{2}{|c|}{197,24} & 0,04 & & & & & & \\
\hline
\end{tabular}

TABELA 5

Kanoničke struktura normalnih i patoloskkih konativnih varijabli.

\begin{tabular}{cccccc}
\hline \multicolumn{2}{c}{ Normalni konativni faktori } & \multicolumn{4}{c}{ Patološki konativni faktori } \\
\hline & Fc-1 & Fc-2 & & Fc-1 & Fc-2 \\
\hline A & $-0,14$ & 0,04 & K10 & 0,37 & $-0,07$ \\
\hline B & $\mathbf{0 , 2 8}$ & $-0,19$ & G11 & 0,40 & 0,32 \\
\hline C & $\mathbf{0 , 3 7}$ & $-0,09$ & I7 & 0,49 & 0,17 \\
\hline E & 0,22 & 0,08 & H13 & $\mathbf{0 , 4 1}$ & $\mathbf{0 , 5 7}$ \\
\hline F & 0,00 & $-0,10$ & A1 & 0,19 & 0,21 \\
\hline G & $-0,03$ & $-0,01$ & O3 & 0,16 & $-\mathbf{0 , 3 2}$ \\
\hline H & $\mathbf{0 , 3 5}$ & $-0,17$ & S5 & $-0,05$ & 0,16 \\
\hline I & $\mathbf{- 0 , 3 5}$ & $-0,20$ & F2 & $\mathbf{0 , 3 0}$ & $\mathbf{0 , 5 5}$ \\
\hline L & $\mathbf{0 , 3 1}$ & 0,22 & N14 & $-0,24$ & $\mathbf{0 , 4 2}$ \\
\hline M & $-0,01$ & $-0,20$ & T15 & 0,20 & 0,15 \\
\hline N & 0,04 & $\mathbf{0 , 3 0}$ & P18 & $\mathbf{0 , 3 0}$ & $-0,05$ \\
\hline O & $-0,00$ & $-0,13$ & D6 & $-0,01$ & $-0,22$ \\
\hline Q1 & $-0,13$ & 0,03 & & & \\
\hline Q2 & $\mathbf{- 0 , 3 9}$ & $\mathbf{0 , 4 2}$ & & & \\
\hline Q3 & 0,17 & $\mathbf{0 , 3 2}$ & & & \\
\hline Q4 & 0,17 & $\mathbf{0 , 5 6}$ & & & \\
\hline
\end{tabular}


zijama. Vispreniji, pronicljiviji i diskretniji ispitanici pokazuju veću sklonost ka inhibitornim konverzijama, anksioznosti, fobičnosti i impulsivnom reagovanju. Oni koji su zabrinutiji, nesigurniji, često okrivljuju sebe za sve su manje skloni agresivnosti. Otvoreniji za promjene, liberalniji, analitičniji i kritičniji rukometaši imaju manje skorove na hipohondriji, opsesivnosti i paranoidnosti. Ispitanici koji su samodovoljniji i samopouzdaniji skloniji su opsesivnosti, a oni skoni perfekcionizmu, kompulsivnosti i samodisciplini, koji pokazuju tendenciju ka nadmoćnom ponašanju uz dosta samosažaljenja su pod većim rizikom za gastrointestinalnu i inhibitornu konverziju i impulsivniji su. Napeti, energični, nestrpljivi rukometaši češće razvijaju gastroingestinalnu konverziju, hipohondriju i fobičnost.

Proučavanjem odnosa morfoloških karakteristika i patoloških konativnih faktora na uzorku od 836 muškaraca, uzrasta 19-21 godine, pripadnika klinički zdrave populacije su se u svom istraživanju bavili Hošek i Momirović (1992). Iako ovi autori kažu da se hipoteze o povezanosti morfoloških karakteristika ne moraju a priori odbaciti, rezultati dobijeni u našem istraživanju pokazuju da nijedna od morfoloških karakteristika nije značajno korelirala sa patološkim konativnim faktorima. Čak su i Hošek i Momirović (1992) dobili da postoji samo jedna statistički značajna korelacija između seta koji je merio svega sedam morfoloških karakteristika (visina, težina, biakromijalni raspon, srednji obim grudi, obim opružene nadlaktice, obim potkoljenice i kožni nabor nadlaktice) i faktora obuhvaćenih testom. Ta razlika, iako statistički značajna, bila je veoma niska i sami autori smatraju da se ovakvi rezultati mogu pripisati tendenciji da muškarci snažne tjelesne građe imaju slabiju regulaciju funkcije reakcije napada, odnosno, da su posmatrano u terminima faktora, skloniji agresivnom i impulsivnom reagovanju u situacijama ugroženosti i frustracije. Njihova pretpostavka se u našem istraživanju nije pokazala kao opravdana, tim prije što je istraživanjem bilo obuhvaćeno čak 23 morfološke karakteristike i to na visoko selekcionisanom uzorku, budući da je riječ o rukometašima koji nastupaju u Prvoj ligi i da rukomet kao takav zahtijeva igrače izrazito snažne i naglašene tjelesne konstitucije, pa samim tim i natprosječnih antropomorfoloških odlika u odnosu na opštu populaciju.

\section{ZAKLJUČAK}

Efikasnost u obavljanju bilo koje ljudske aktivnosti nije nezavisna od osobina koje regulišu modalitete čovjekovog ponašanja, pa samim tim i u ru- kometu. Naime, poznato je da neke osobine iz konativnog prostora ograničavaju efikasnost u različitim aktivnostima direktno, a u nekim drugim idirektno (nap., zbog kontaminirajućeg djelovanja na neke druge antropološke osobine, sposobnosti ili karakteristike). Nije isključena ni mogućnost da u nekim aktivnostima iste konativne osobine predstavljaju restriktor, a u nekim stimulator efikasnosti, posebno u situacijama kada učestvuju u uspjehu određene aktivnosti. U vezi s tim, vrijedi i pravilo da ne postoje dva subjekta kod kojih bi bila potpuno istovjetna struktura bilo kojih, pa i konativnih osobina, bez obzira na njihov konačni broj. Iz tih razloga je poznavanje kompleksiteta neke aktivnosti, u koji spada i prostor konativnih karakteristika, važna pretpostavka operacionalizacije cilja svake aktivnosti, pa shodno tome i rukometa. Dobijeni rezultati u ovom radu govore da se rukometaši ektomezomorfnog tipa karakterišu na jednom polu - longitudinalnim merama a na drugom transverzalnom dimenzionalnošću i obimom femoralne regije ako su ekstravertni i neanksiozni. Kod rukometaša ovog ranga takmičenja, kod kojih je izraženije toplo ponašanje, koji su ljubazniji, pažljiviji prema drugima postoji porast skorova na depresivnosti kao i kod onih koji pokazuju izraženiju živahnost $\mathrm{i}$ impulsivnost i ekspresivnost. Rukometaši koji češće manifestuju dominantno, takmičarsko, asertivno ili čak agresivno ponašanje su skloniji anksioznosti. Oni koji su moralističniji i više poštuju pravila su skloniji hipersenzitivnosti, a oni koji su neustrašiviji i avanturustički nastrojeni imaju više skorove na opsesivnosti. Napeti, energični, nestrpljivi rukometaši češće razvijaju gastroingestinalnu konverziju, hipohondriju i fobičnost.

\section{LITERATURA}

Cattell, R. B., Eber, H. W., \& Tatsuoka, M. (1970). Handbook for the Sixteen Personality Factor

Qustionnaire. Champaign, ILL: Institute for

Personality and Ability Testing.

Gabrijelić, M. (1977). Manifestne i latentne dimenzije urhunskih sportista nekih momčadskih sportskib igra u motorickom, kognitivnom i konativnom prostoru

[Manifest and latent dimensions of elite athletes some TEAM sport plays in motor, cognitive and cognitive space]. Unpublished doctoral dissertation, University of Zagreb, Fakultet za fizičku kulturu.

Havelka, N., \& Lazarević, Lj. (1981). Sport i ličnost [Sport and personality]. Belgrade, RS: Sportska knjiga.

Herdis, L., Deabler, E., Hartl, M., \& Willis, C. A. (1973). Physique and personality: somatotype 
and the 16 PF. Perceptual and Motor Skills, 36, 927-933. doi: 10.2466/pms.1973.36.3.927

Hol, S. K., \& Lindzi, G. (1983). Teorije ličnosti [Theories of personality]. Beograd, RS: Nolit.

Hošek, A., \& Momirović, K. (1992). Prilog poznavanju odnosa između morfoloških karakteristika i osobina ličnosti [Contribution to the knowledge of the relationship between morphological characteristics and personality traits]. Psihologija, 3-4, 36-42.

Ilić, S. (1993). Relacije bazično-motoričkih i situacionomotorickih sposobnosti u rukometu [Relationships basic-motor and situational-motor skills in handball]. Unpublished master's thesis, University of Belgrade, Fakultet fizičke kulture.

Katel, R. B. (1978). Naućna analiza ličnosti [Scientific analysis of personality]. Beograd, RS: BIGZ.

Kretschmer, E. (1970). Physique and character. New York, NY: Cooper Square.

Malacko, J., \& Popović, D. (2001). Metodologija kineziološko antropoloških istraživanja

[Methodology of Kinesiology and anthropological research]. Leposavić, RS: Fakultet za fizičku kulturu.

Momirović, K. (1971). Struktura i mjerenje patoloških konativnih faktora [Structure and measurement of cognitive pathological factors]. Zagreb, HR: Republički zavod za zapošljavanje.

Pajević, D. (2003). Psibologija sporta i rekreacije [Psychology of sport and recreation]. Laktaši, BA: Grafomark.

Pokrajac, B. (1983). Telesni i motorickei status rukometaša u odnosu na takmičarski nivo $i$ komparativna analiza sa sportistima drugih sportskih igara [Physical and motor status of handball in relation to the competitive level and comparative analysis with athletes of other sports games]. Unpublished doctoral dissertation, University of Belgrade, Fakultet fizičkog vaspitanja.

Popović, D., \& Simonović, M. (2008). Psihologija $i$ psibologija sporta Psychology and psychology of sport]. Leposavić, RS: Fakultet za sport i fizičko vaspitanje.

Popović-Ilić T., Stanković V., Vitošević B., \& Ilić S. (2010). Struktura morfoloških dimenzija vrhunskih sportista [Structure of the morphological dimensions of elite athletes]. Praxis medica, 38(3-4), 63-70.

Powell, A., \& Royce, J.R. (1981). An overwiev of a multifactor - system theoory of personality and social differences: The factor and system models and the hiearchical factor structure of individuality. Journal of Personality and Social Psychology, 41(4), 818-829. doi: 10.1037/00223514.41.4.818

Sheldon, W. H., \& Stevens, S. S. (1942). The varieties of temperament: a psychology of constitutiond differences. New York, NY: Harper.

Srhoj, V., Marinović, M., \& Rogulj, N. (2002). Position specific morphological characteristics of top-level male handball players. Collegium antropologicum, 26(1), 219-227. PMid: 12137302

Stanković, V. (2000). Testiranje i primena programa za utvrdivanje strukture i razlika u medusobno povezanim prostorima kod rukometaša u toku jednogodišnjeg trenažnog procesa [Testing and implementation of programs for the determination of structure and the difference in the interrelated areas of the handball players during a one-year training process]. Unpublished doctoral dissertation, University of Priština, Fakultet za fizičku kulturu.

Stanković, V. (2001). Osnove primenjene kineziologije [Basic of applied kinesiology]. Leposavić, RS: Fakultet za fizičku kulturu.

Stanković, V., \& Malacko, J. (2008). Relations between systems of motor, cognitive and conative variables of top-class handball players. Kinesiologia Slovenica, 3(14), 33-44.

Stanković, V., Malacko, J., \& Doder, D. (2009). The differences in morphological characteristics among top handball, basketball and football players. Acta Kinesiologica, 3(2), 90-94.

Stanković, V., Malacko, J., \& Doder, D. (2011). Comparative analiysis of factor structures of latent variables of pathological connate characteristics in case of handball players belonging to different competition ranks. Acta Kinesiologica, 5(2), 58-62.

Stanković V., \& Popović M. (2011). Identifikacija morfoloških karakteristika povezanih sa horizontalnim osovinama rukometaša i fudbalera [Identification of morphological characteristics associated with the horizontal axis and handball players]. Praxis medica, 39(1-2), 55-58.

Szirovicza, L., Momirović, K., Hošek, A., \& Gredelj, M. (1980). Latentne morfološke dimenzije određene na temelju faktorskog $i$ taksonomskog modela u standardiziranom image prostoru [Latent morphological dimensions determined on the basis of factor and taxonomic models in a standardized image space]. Kineziologija, 10, 15-20.

Šentija, D, Matković B, Vuleta D, Tomljanović M, \& Džaj, I. (1997). Funkcionalne sposobnosti vrhunskih rukometaša i rukometašica 
[Functional abilities of top handball players]. In D. Milanović D and S. Heimer S. (Eds.), Dijagnostika trenirnosti sportaša (pp. 36-39). Zagreb, HR: Fakultet za fizičku kulturu.

Šibila, M., \& Pori, P. (2009). Position-related differences in selected morphological body characteristics of top-level handball players. Collegium antropologicum, 33(4), 1079-1086. PMid: 20102051
Vrbik, I., Čižmek, A., \& Gruić I. (2011).

Morfološke karakteristike između igračkih pozicija kod vrhunskih rukometaša

[Morphological characteristics between playing positions in elite handball players]. Hrvatski športskomedicinski vjesnik. 26(2), 94-99.

Primljeno: 7. oktobra 2013. godine Izmjene primljene: 12. decembra 2013. godine

Odobreno: 21. decembra 2013. godine

Korespondencija: Dr Veroljub Stanković Fakultet za sport i fizičko vaspitanje Univerzitet u Prištini Dositeja Obradovića bb 38218 Leposavić Srbija Telefon: 00381648904600 E-mail: veroljub.stankovic@pr.ac.rs 